\title{
NUMERICAL AND EXPERIMENTAL DETERMINATION OF WIND LOAD ON PHOTOVOLTAIC PANEL ASSEMBLIES
}

\author{
NUMERIČKO I EKSPERIMENTALNO ODREĐIVANJE OPTEREĆENJA \\ KOJE VETAR VRŠI NA SKLOPOVE FOTONAPONSKE PLOČE
}

\author{
Ol'ga HUBOVÁ \\ Michal FRANEK \\ Marek MACÁK
}

\section{INTRODUCTION}

Presently, solar panels represent one of the possible alternative energy sources in our climate zone. They can be located on the roofs of buildings, but also on the ground as solar power plants. Depending on the shape of the terrain, various geometric panel assemblies have been designed to obtain maximum energy from the sun and to use the available lands. Design and arrangement of photovoltaic (PV) and photothermal (PT) panels, generally called the solar collectors, is mainly affected by the electric and thermal efficiency of collectors. Only a limited research was done on the wind loads of panels and their supporting structures so far. Designers of PV panels often use applicable standards, in our region the STN EN 1991-1-4 [18, 19] in which the panel is considered as a monopitch canopy. Early wind studies describing the experimental investigation of ground mounted solar collectors and their supporting systems were published by Miller and Zimmerman [14]. They focused on the techniques to predict dynamic response and the structural dynamic loads of PV panels due to the wind turbulence. They identified, that the largest response and dynamic magnification factor occurred at mid chord location on an array and near the trailing edge. A significant decrease of wind loads was observed on interior to the array field.

Ol'ga Hubová, Associate Professor, Slovak University of Technology, Department of Structural Mechanics, 81005 Bratislava, Slovakia, e-mail: olga.hubova@stuba.sk

Michal Franek, Assistant Professor, Slovak University of Technology, Department of Building Construction, 81005 Bratislava, Slovakia, e-mail: michal.franek@stuba.sk

Marek Macák, Assistant Professor, Slovak University of Technology, Department of Mathematics and Descriptive Geometry, 81005 Bratislava, Slovakia, e-mail: marek.macak@stuba.sk
ORIGINALNI NAUČNI RAD ORIGINAL SCIENTIFIC PAPER UDK:621.383.51

doi:10.5937/GRMK2004049H
Franklin [10] performed a dynamic analysis on a panel assembly. His conclusions show that the array of panels can be divided into two zones. The edges of the field reach the value of the wind force coefficient higher than 0.30 , the maximum is around 0.8 and the wind force coefficient of the inner zone is lower than 0.30 . The torque is also higher only in the area of the field edges. Radu and Axinte [16] performed experimental wind pressure measurements to evaluate suction factor on a panel support system. Recent works by Strobel and Banks [20] have shown that panels placed on the ground are prone to oscillations with frequencies above $1 \mathrm{~Hz}$, which is contrary to the regulations in ASCE 7. Warsido et al. [22] investigated a group of panels placed on the terrain and the effect of the distance between rows of panels on the wind load. They found that the coefficient of force and moment from the wind for a group of panels decreases along the rows of panels, which is caused by the shielding effect of the front panels. The largest reduction in wind load was measured in the second row of panels; load reductions after the fourth row were minimal.

Detailed research of wind load on solar panels located on the ground is provided by technical report no. 64 by Bodhinayake, Ginger and Ingham [6]. This report determines the net pressure factor for the design of PV modules. The highest values of the net pressure coefficient were measured at the upper edge of the panel when the wind flowed towards the lower surface of the inclined panels. The increasing use of $\mathrm{PV}$ panel assemblies on the roofs of residential buildings leads to wind load research for this type of panel placement [16, $7,12,15]$. Advanced numerical methods with computer simulation of fluid flow were used in work Bitsumlak et al. [4], where the assembly of three free-standing panels in tandem arrangement only for one wind direction $\left(180^{\circ}\right)$ 
was analyzed. As a result of the CFD simulation using Large Eddy Simulation (LES), it was found that by placing another panel in front of the examined panel, the wind load is significantly reduced. Meroney and Neft [13] used CFD simulation of roof panels to compare with experimental results from a wind tunnel. Shademan et al. [17] investigated for the $0^{\circ}$ wind direction the effect of the distance between rows of panels placed on the ground, at an angle of $45^{\circ}$. They used the turbulent Shear Stress Transport (SST) model $k-\omega$. It was found that the distance between the rows has insignificant effect on the load of the first row of panels in the windward part. However, for the rest of the rows, increasing the distance between the rows increased the drag coefficient and decreased the buoyancy coefficient. Jubayer and Hangan [11] used a 3D Reynolds-Averaged Navier-Stokes (RANS) simulation with an unsteady solver and Shear Stress Transport (SST) $k-\omega$ turbulence model. This article provides a detailed analysis of the wind load on a group of solar panels for the direct $\left(0^{\circ}\right.$ and $\left.180^{\circ}\right)$ but also for the oblique $\left(45^{\circ}\right.$ and $\left.135^{\circ}\right)$ wind directions. Wind speeds and wind pressure distributions for all panel assemblies are listed here.

The aim of our research - numerical simulation and experimental measurements - was to determine the wind load for a rectangular panel assembly and to determine the wind load values of the upper and lower surfaces of individual solar panels in different rows. Slovak national standard STN EN 1991-1-4 [18, 19] fails to include groups of panels or open roofs arranged in rows and exposed to wind, and therefore the values for the design of an open roof are based on the provisions of Table 7.6 in [18]. The resulting wind force coefficients $c_{f}$ and net pressure coefficients $c_{p, \text { net }}$ take into account the combined effect of wind on the upper and lower surface of the canopies for all wind directions.

Since existing standards consider wind loads only for typical object shapes, wind tunnel tests on models were used for a better understanding of the wind effects on a particular objects arrangement in a given location and also determine local extreme loads on individual surfaces. The wind flow in Boundary Layer Wind Tunnel (BLWT) represents with technical accuracy the wind flow in the lower part of the atmosphere up to about $200 \mathrm{~m}$ above the ground, where the objects are located. BLWT STU tunnel with modelled boundary layer allows repeated measurements for different wind directions and speeds. Wind effect on structures can be observed in model reduction experimentally, and the most unfavourable effects of wind on the objects can be determined.

\section{NET PRESSURE COEFFICIENT}

STN EN 1991-1-4 [18] provides a procedure for determination of the net pressure coefficient $c_{p}$,net, which is defined as the difference between the pressures on the opposite surfaces for monopitch canopies. The force coefficient and the net pressure coefficients after interpolation (Figure 1 and Table 1) for free-standing canopy with inclination $27^{\circ}$ can be found in [18].

Net Pressure coefficients $c_{p, n e t}$

Key plan

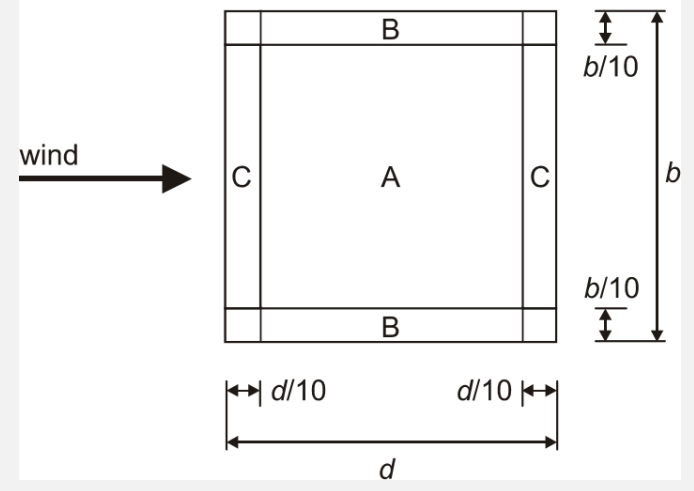

Figure 1. Key plan of zones for monopitch canopies [18]

Table 1. Interpolated values of net pressure coefficient for monopitch canopies

\begin{tabular}{|c|c|c|c|}
\hline $\begin{array}{c}\text { Roof angle } \\
\boldsymbol{\alpha} \\
{\left[{ }^{\circ}\right]}\end{array}$ & Zone & $\begin{array}{c}\text { Downward } \\
\text { wind action } \\
\text { Cp,net } \\
{[-]}\end{array}$ & $\begin{array}{c}\text { Upward } \\
\text { wind action } \\
\text { Cp,net } \\
{[-]}\end{array}$ \\
\hline \multirow{3}{*}{27} & A & 2.08 & -2.76 \\
\cline { 2 - 4 } & B & 3.14 & -3.44 \\
\cline { 2 - 4 } & C & 2.34 & -3.36 \\
\hline
\end{tabular}


Wind pressure coefficients for the upper and lower table surfaces were experimentally obtained from the values of wind pressure in the form as follows:

$$
c_{p}=\frac{\Delta p}{p_{\text {dyn }}\left(z_{\text {ref }}\right)}=\frac{p(t)-p_{0}}{\frac{1}{2} \cdot \rho \cdot v_{m}{ }^{2}\left(z_{\text {ref }}\right)}
$$

where $\Delta p$ is difference pressure $[\mathrm{Pa}], p(\mathrm{t})$ is the wind pressure in measuring point on the surface of the model $[\mathrm{Pa}]$ and $p 0$ is static pressure of undisturbed flow $[\mathrm{Pa}$. Dynamic pressure of the mean wind velocity $p_{\text {dyn }}$ was considered in reference height $z$ ref (in our case, reference height was equalled to the height of the top of examined panel), $\rho$ is air density $\left[\mathrm{kg} / \mathrm{m}^{3}\right], v_{\mathrm{m}}\left(z_{\mathrm{ret}}\right)$ is mean wind velocity in reference height $(\mathrm{m} / \mathrm{s})$.

The resulting net wind pressure coefficient $C_{p}$,net was calculated as the difference between the values from the upper and lower table surfaces according to the relation:

$$
c_{\text {pinet }}=c_{\text {pupper }}-c_{\text {plower }}
$$

If the resulting pressure is negative, the table is loaded by suction, at a positive value it is the wind pressure. The evaluation of the results of the experimental and numerical approach for the rectangular assembly was plotted as resulting net wind pressure coefficients.

\section{GEOMETRY OF PHOTOVOLTAIC PANNEL ASSEMBLIES}

External wind pressures corresponding to the reference wind speed at the top of the model were measured at two altitude levels along the panel. The location of the sampling points was selected based on the results of CFD simulation. One panel had $40 \times 4 \mathrm{~m}$ (length $\times$ width) with tilt angle $27^{\circ}$, which represented one table. The total number of sampling points on one solar table was 43 on upper and 43 on lower part. Panels were placed in series of 3 without gap, which represented one row. There were 8 rows with rectangular assembly. Gap between rows was $4.536 \mathrm{~m}$ (Figure 2 ).

\section{NUMERICAL SIMULATION (CFD)}

The aim of the numerical simulation was to pre-define the wind pressure distribution for the panel assemblies for different wind directions with a step of $22.5^{\circ}$. The results from the simulation helped to place the pressure taps on the model and the numerical results were used for comparison with the experimental measurements.

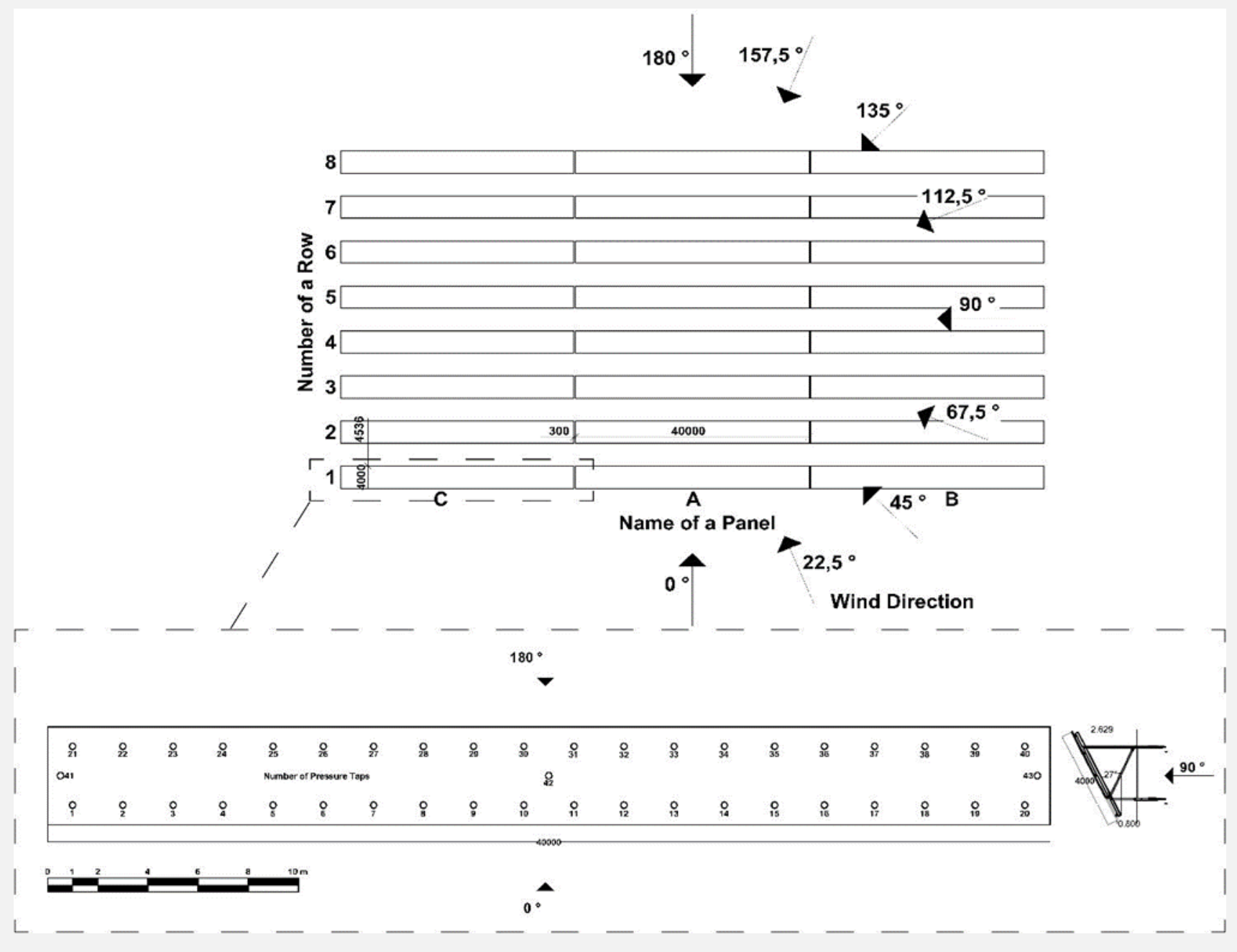

Figure 2. Arrangement of panel assembly with layout of pressure taps 


\subsection{Numerical model}

Numerical simulation was solved in the program ANSYS Fluent [2, 3], which allows a detailed definition of the problem and its solution and contains the most comprehensive set of mathematical models used in many applications.

The Realizable $k-\varepsilon$ model was used in numerical simulations. It is a two-equation model in which the calculation of the turbulent dynamic viscosity in the equation for the Bussinesque's hypothesis is solved using two separate transport equations and allows to determine the turbulent kinetic energy $k$ and the dissipation of turbulent kinetic energy $\varepsilon$. The chosen Realizable $k-\varepsilon$ model solves the transport equation for the transfer of turbulent kinetic energy $k$ in the form as follows
This turbulent model is characterized by high accuracy near the walls, while the accuracy in the open terrain is average.

\subsection{Computational domain}

The size of the computation domain was chosen $600 \times 400 \times 50 \mathrm{~m}^{3}$ (length $\times$ width $\times$ height) taking into account the recommendations in $[9,21]$, so that the block ratio between the size of objects and the computational area is less than $3 \%$, which guarantees that the results will not be affected by the boundary of the computational domain (Figure 3).

$$
\frac{\partial}{\partial t}(\rho k)+\frac{\partial}{\partial x_{j}}\left(\rho k u_{j}\right)=\frac{\partial}{\partial x_{j}}\left[\left(\mu+\frac{\mu_{t}}{\sigma_{k}}\right) \frac{\partial k}{\partial x_{j}}\right]+G_{k}+G_{b}-\rho \varepsilon-Y_{M}+S_{k *}
$$

Dissipation of turbulent kinetic energy $\varepsilon$ is calculated by the equation:

$$
\frac{\partial}{\partial t}(\rho \varepsilon)+\frac{\partial}{\partial x_{j}}\left(\rho \varepsilon u_{j}\right)=\frac{\partial}{\partial x_{j}}\left[\left(\mu+\frac{\mu_{t}}{\sigma_{s}}\right) \frac{\partial \varepsilon}{\partial x_{j}}\right]+\rho C_{1} S_{s}-\rho C_{2 s} \frac{\varepsilon^{2}}{k+\sqrt{v \varepsilon}}+C_{1 s} \frac{\varepsilon}{k} C_{3 s} G_{b}+S_{s x}
$$

where $u$ is wind speed [m/s], $t$ is time [s], $k$ is turbulent kinetic energy $\left[\mathrm{m}^{2} / \mathrm{s}^{2}\right], \varepsilon$ is dissipation of turbulence kinetic energy $\left[\mathrm{m}^{2} / \mathrm{s}^{3}\right], v$ is kinematic viscosity $\left[\mathrm{m}^{2} / \mathrm{s}\right], \mu_{\mathrm{t}}$ is turbulent dynamic viscosity, $\sigma$ is turbulent Prandtl number $[-], G_{k}$ expresses the change in turbulent kinetic energy due to the change in velocity gradient, $\rho C_{1} S_{\varepsilon}$ is the productive member, $C_{2}$ is the model constant and $\rho$ is the air density $\left[\mathrm{kg} / \mathrm{m}^{3}\right]$.

\subsection{Computational mesh}

The computational mesh was generated using an adaptive function and polyhedral elements. The size of the elements on the examined object was set to $0.2 \mathrm{~m}$ using the distance and curvature function. An inflatable function with five layers and the first layer size of $0.02 \mathrm{~m}$ was used for the investigated solar panel system. The generated mesh had $18087 \quad 614$ computing nodes (Figure 4).

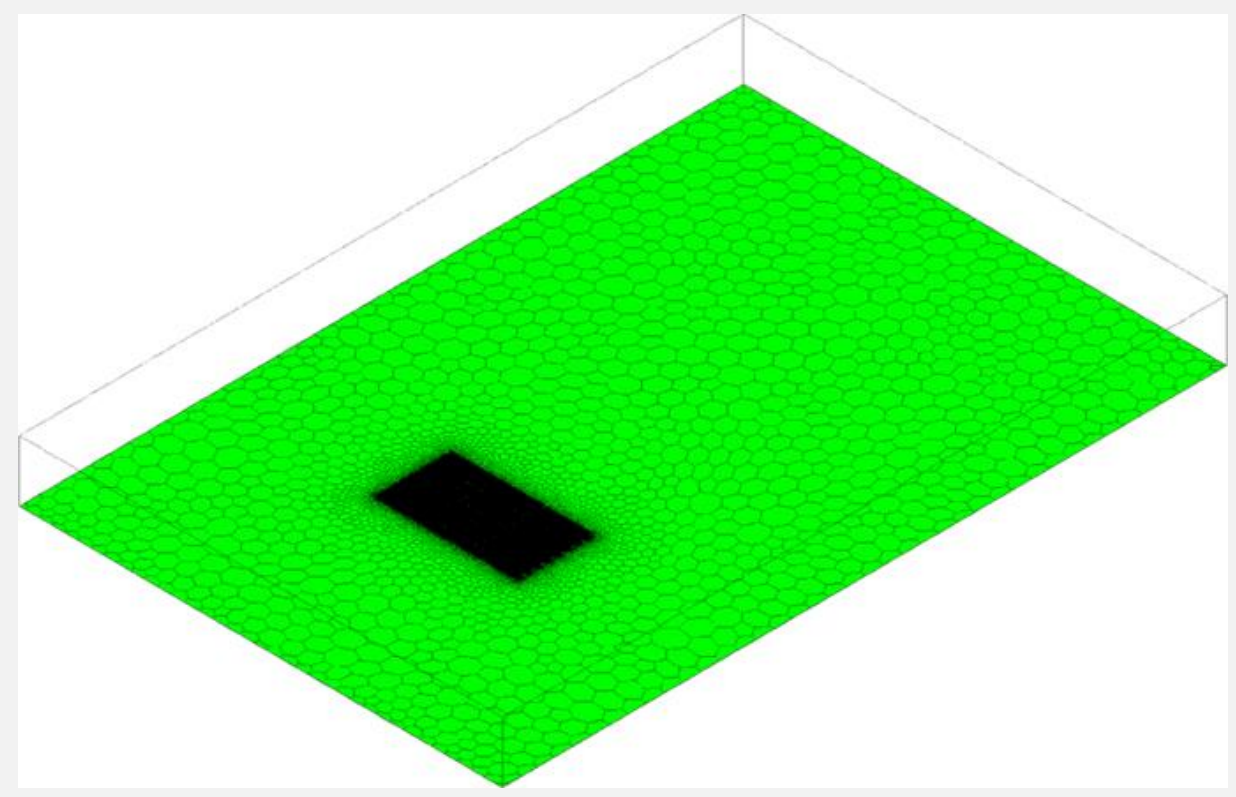

Figure 3. Computational domain with mesh 


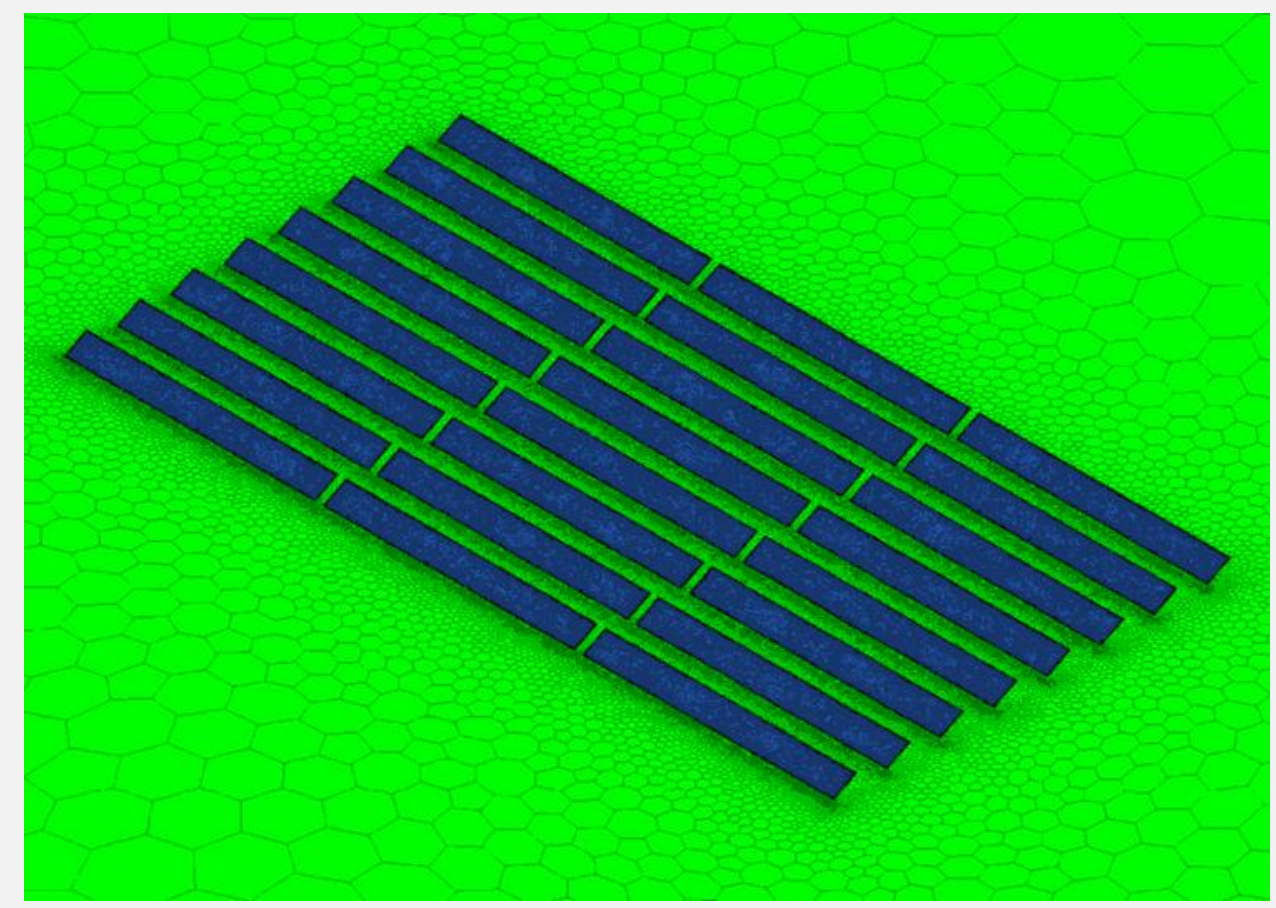

Figure 4. Detail of computational mesh

\subsection{Boundary conditions}

The input to the calculation area was set as Inlet using the logarithmic function of the wind profile as follows:

$$
\begin{aligned}
& v(z)=\frac{v^{*}}{K} \ln \frac{z+z_{0}}{z_{0}} \\
& v^{*}=\frac{v_{\text {ref }} K}{\ln \frac{z_{\text {ref }}+z_{0}}{z_{0}}}
\end{aligned}
$$

where $v(z)$ is the mean wind speed at height $z, v^{*}$ is the friction speed, $z_{0}$ is the aerodynamic roughness length (for smooth terrain it is 0.005 ), $K$ is von Karman constant $(K=0.42)$, vref is the reference wind speed, which had a value of $8.15 \mathrm{~m} / \mathrm{s}$ at a reference height at the level of the upper edge of the panel.

Turbulence at the entrance to the computational domain was modelled using the relations:

$$
\begin{gathered}
k=\frac{v^{* z}}{\sqrt{C_{\mu}}} \\
\varepsilon=\frac{v^{* 3}}{\kappa\left(z+z_{0}\right)}
\end{gathered}
$$

where $C_{\mu}=0.09$. These boundary conditions guaranteed a wind profile and turbulence of wind profile identical to the wind tunnel.

The outlet boundary is defined as pressure outflow and the side and upper boundary as zero gradient (symmetry).

\subsection{Setting up the computing environment}

All calculations were run as pressure-based and the task was solved stationary. The numerical scheme was set up as a simple pressure-velocity coupling with second-order discretization without relaxation. Solutions were initialized using hybrid initialization. Due to the used modelling approach RANS and Realizable $k-\varepsilon$ model, the output were the average values of wind pressures in the calculation points of the mesh, which were transformed to the dimensionless coefficient of the resulting wind pressure $c_{p, \text { net }}$

\section{EXPERIMENTAL MEASUREMENT IN BLWT}

The existing standards consider wind loads only for typical object shapes and do not consider surrounding objects modifying wind flow, therefore wind tunnel tests on the models provide a better understanding of the effects of wind on the specific arrangement of objects in a given location and also determine local extreme wind loads on individual areas. Flow in wind tunnels BLWT (Boundary layer wind tunnel) represents with technical accuracy the wind flow in the lower part of the atmosphere up to about $200 \mathrm{~m}$ above the ground, where the objects are located.

The solar panels can be arranged in different formations with gaps between them and therefore it is necessary to obtain experimentally the coefficients of the resulting wind pressure for individual areas and assuming all wind directions. The rear solar collectors are less stressed than those standing in front or on the side. In the BLWT wind tunnel in Bratislava (Figure 5), we tested according to the ASCE recommendation [8], solar panels grouped in the shape of a rectangle with gaps between them at different wind speeds and wind directions. 


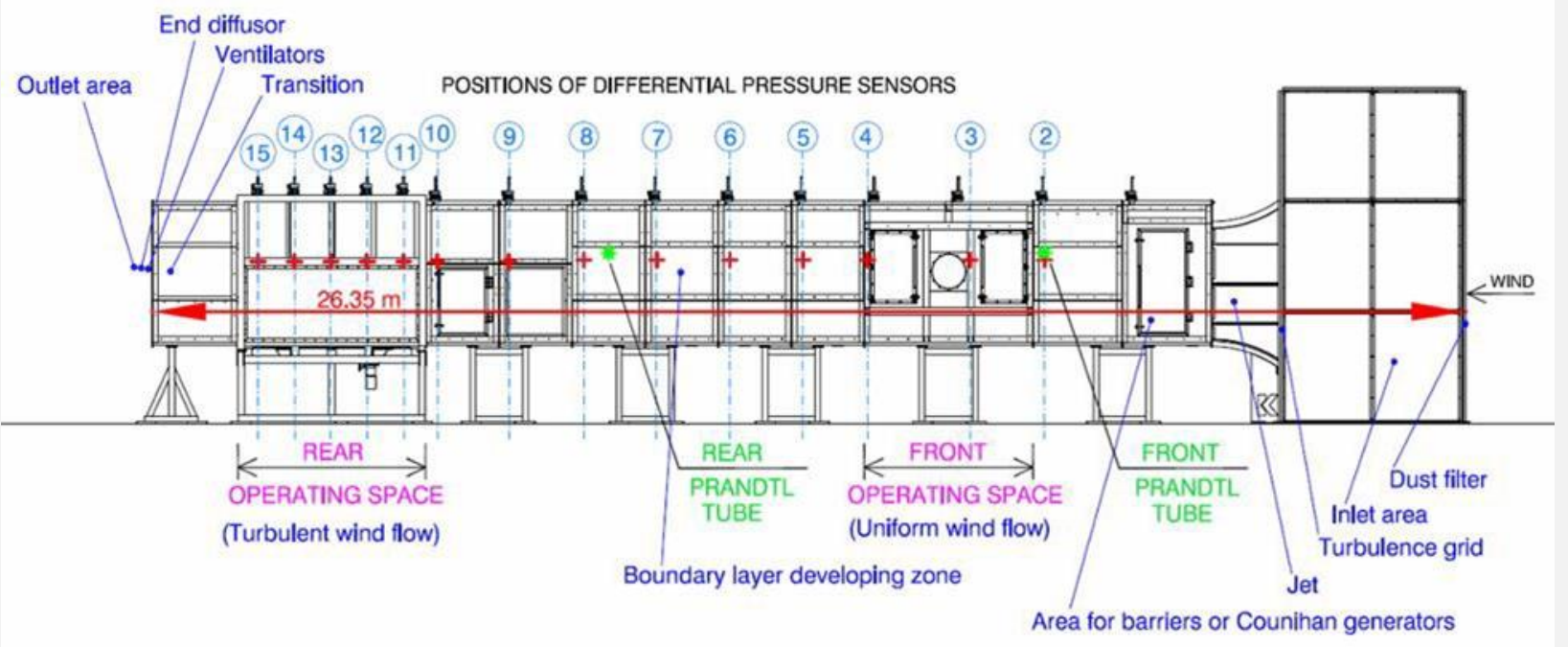

Figure 5. Scheme of BLWT Bratislava

\subsection{Characteristics of Atmospheric Boundary Layer (ABL)}

The solar panel models at a scale of $1: 200$ were placed behind the modelled and experimentally verified boundary layer of smooth terrain (terrain category between I - II). The boundary layer representing the open

terrain was modelled using smooth plates and a barrier. Mean wind velocity and turbulence intensity profiles were compared with Eurocode categorization (Figure 6). The wind flow velocities were set using LabVIEW, which

a)

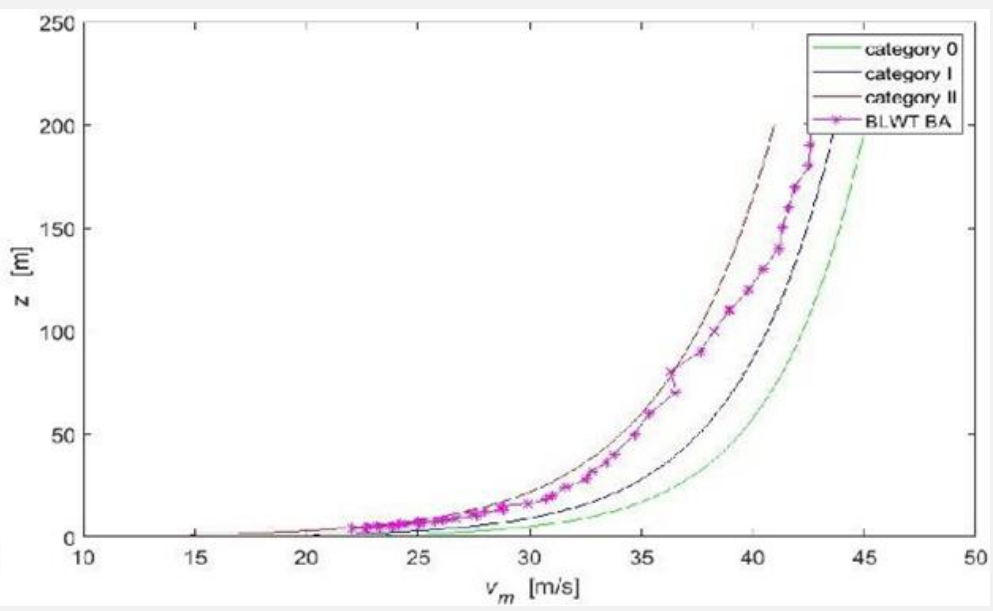

b)

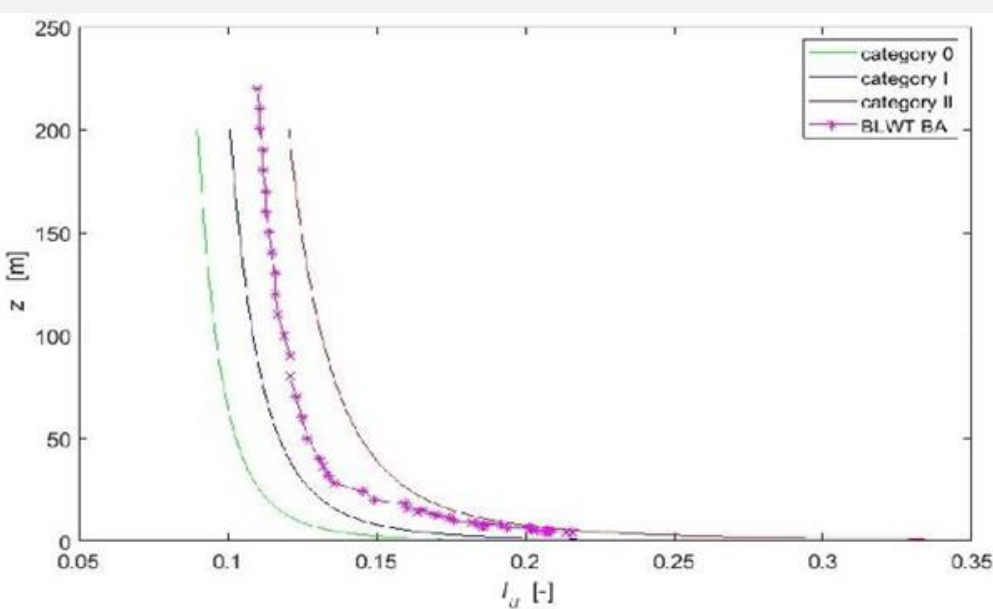

Figure 6. Atmospheric Boundary Layer: a) mean wind velocity profile, b) turbulence intensity profile 
controlled the tunnel depending on the frequency of the inverters and had values of 24 and $28 \mathrm{~Hz}$, which corresponded to the mean values of the reference wind speeds at the top of the photovoltaic panel of 6.965 and $8.15 \mathrm{~m} / \mathrm{s}$ depending on barometric pressure, temperature and air density.

\subsection{Instrumentation}

Pressure sampling points with tubing system and pneumatic connectors were designed for a reduced rigid model of solar panels (Figure 7). Tubing system was conducted to the pressure scanner Scanivalve DSA 3217. Scanner had 16 temperature compensated piezoresistive pressure transducers with a pneumatic calibration valve. 500 samples per one measurement were recorded. It corresponded to sampling frequency for each tap equal to $25 \mathrm{~Hz}$. Lengths of the tubing system and connectors prescribed by the manufacturer were used to eliminate the low pass noise. The duration of one measurement was $20 \mathrm{~s}$. For each measurement it was recorded the time series of difference pressure between the reference tap in Prandtl tube and taps on the model.

\section{RESULTS AND DISCUSSION}

Determination of net pressure coefficients or/and suction on panel assemblies was performed by:

1/ CFD simulation in ANSYS Fluent program
2/ experimental measurements in the BLWT STU tunnel on models of panel assemblies at a scale of 1 :200.

\subsection{Net pressure coefficients distribution}

A rectangular assembly of 8 rows of solar panels was placed on a horizontal smooth terrain, with wind turbulence less than $20 \%$. The dimensionless coefficients of the resulting wind pressure $c_{p, n e t}$ as the difference of the values on the upper and lower surface were determined on the basis of the reference wind speed at the level of the upper edge of the panel. Extreme values of wind effects occurred in both solutions in the same wind direction.

Because the RANS modelling approach and Realizable $k-\varepsilon$ model were chosen to solve the CFD simulation, the output are the average values of wind pressures at the calculation points of the network, which were transformed into a dimensionless resulting wind pressure coefficient $c_{p \text {,net. }}$ For a large number of simulations and measurements, which were solved for all wind directions with a step of $22.5^{\circ}$, the values of the net wind pressure and suction coefficients on the solar panels are depicted for the decisive and critical wind directions $0^{\circ} ; 22.5^{\circ} ; 135^{\circ} ; 157.5^{\circ}$ and $180^{\circ}$ (Figures $8-12$ ). The values of the net pressure coefficient have a + sign and the resulting net suction coefficient has a - sign. The colour range in the figures shows significantly increased loads on the front and side panels and less stress on the inner rows of the photovoltaic panels.

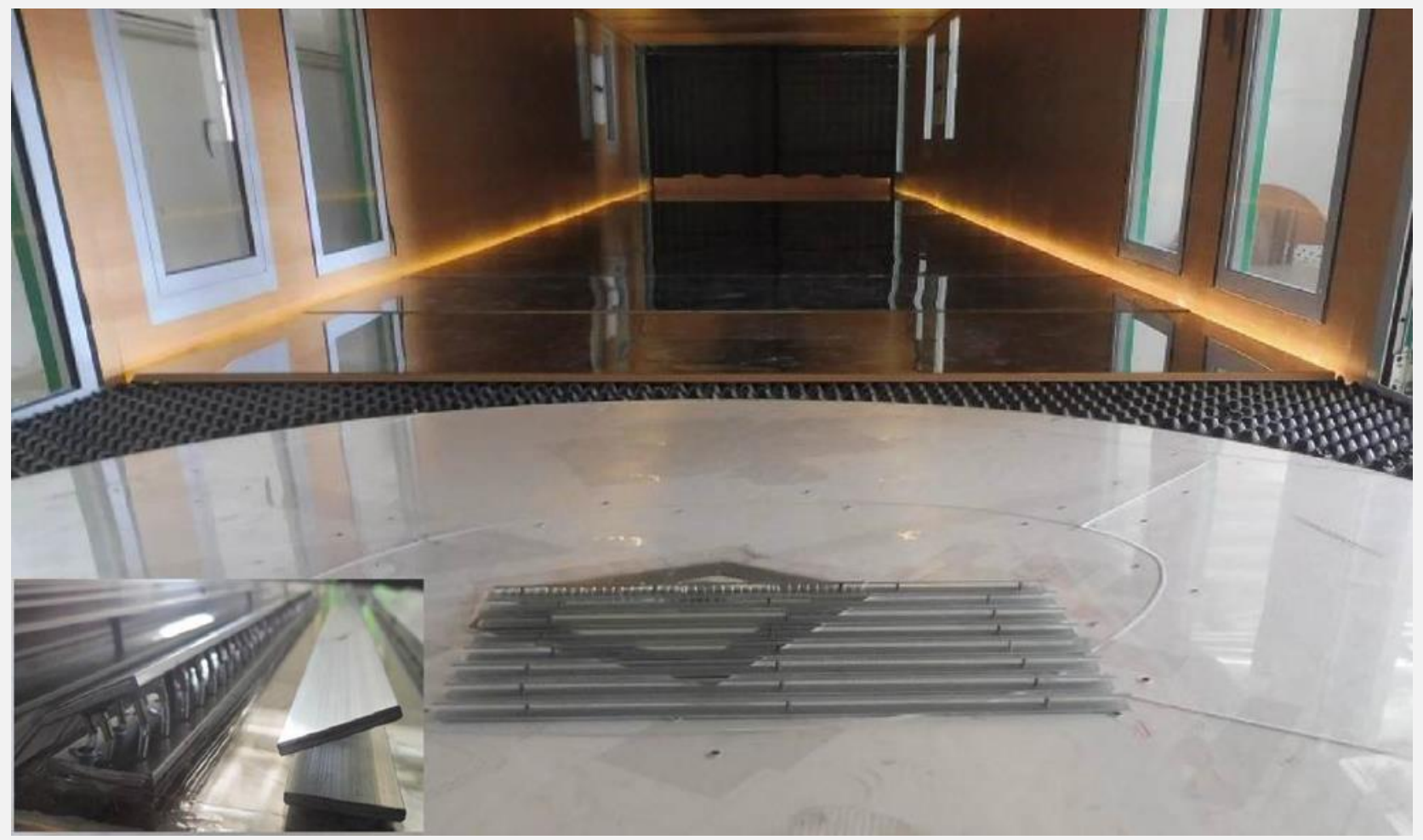

Figure 7. Solar panel assemblies during experiment in BLWT 


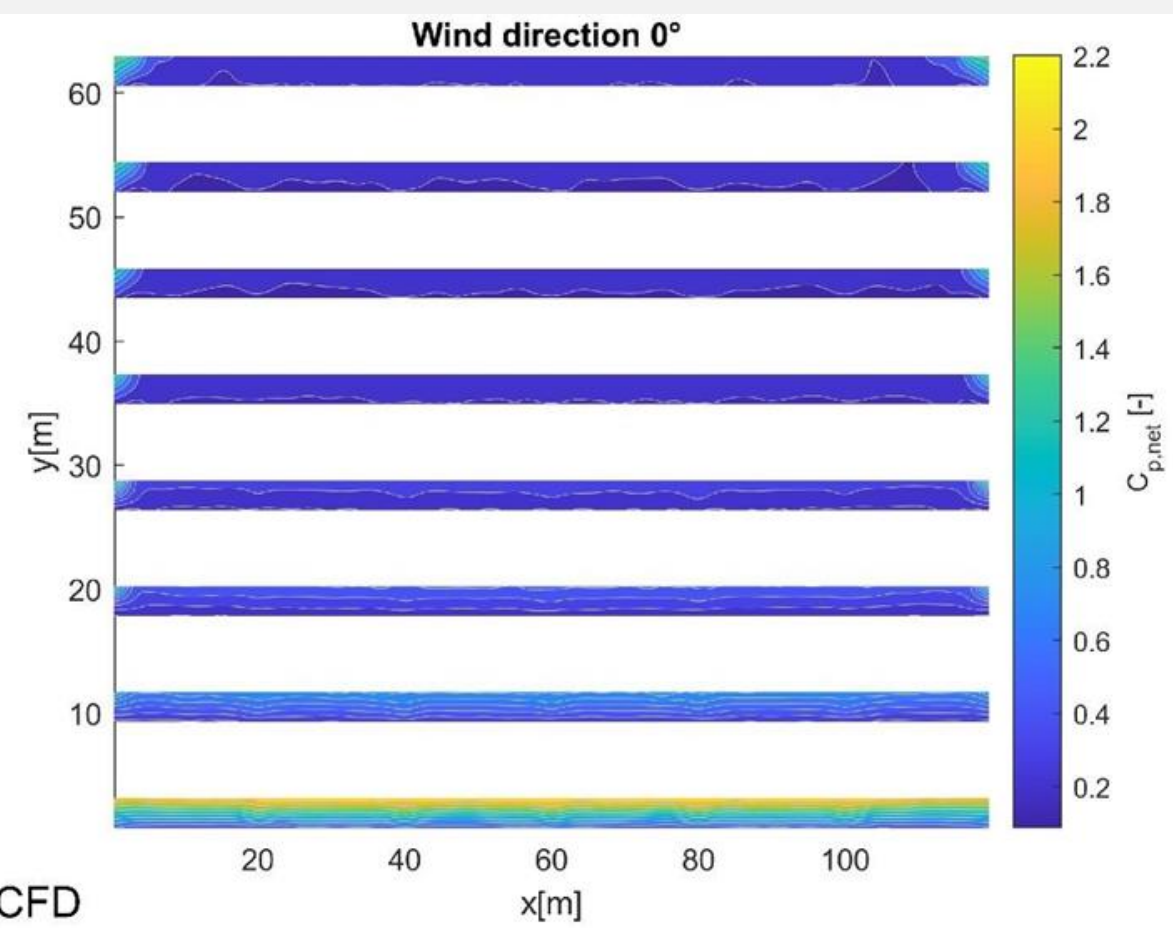

a) CFD

$x[\mathrm{~m}]$

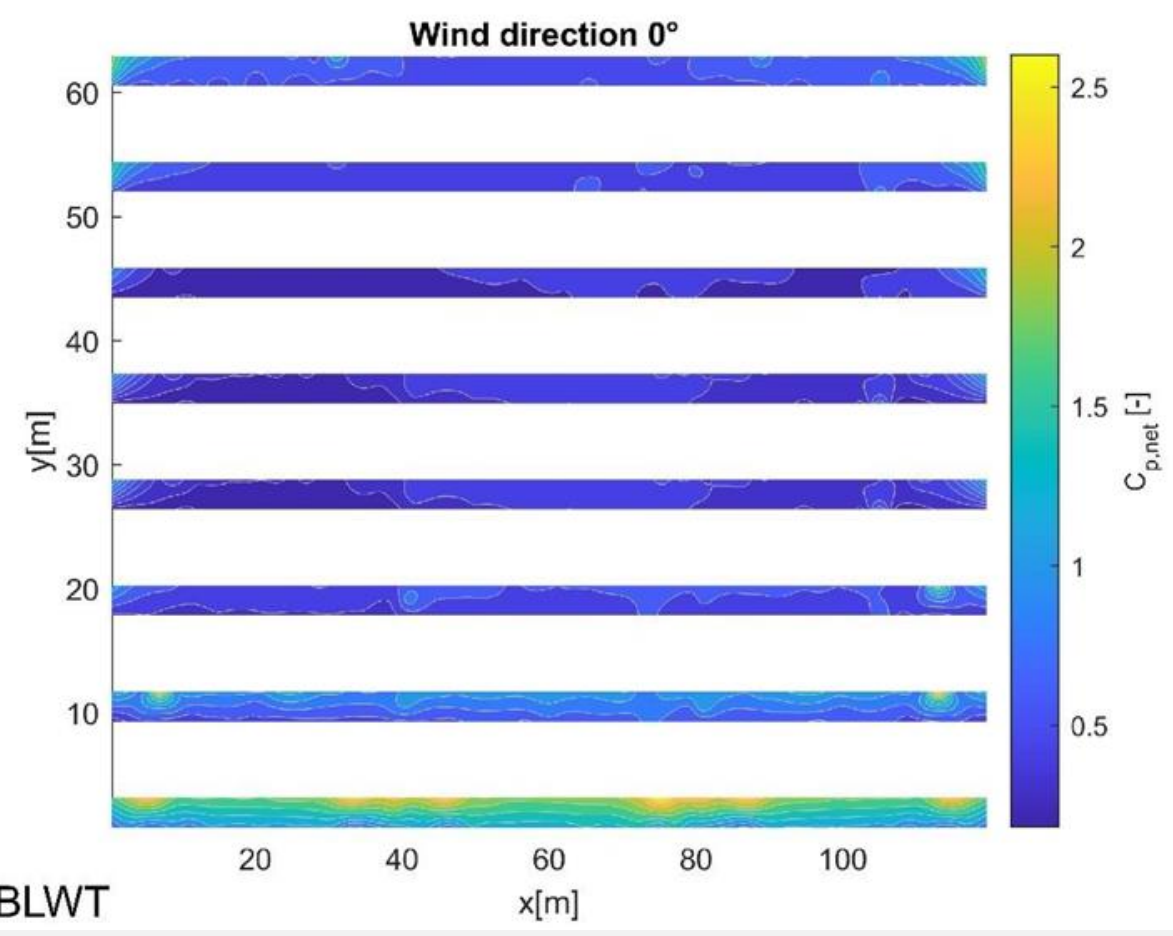

Figure 8. Net pressure coefficients distribution for wind direction $0^{\circ}$ : a) results from simulation, b) results from wind tunnel 


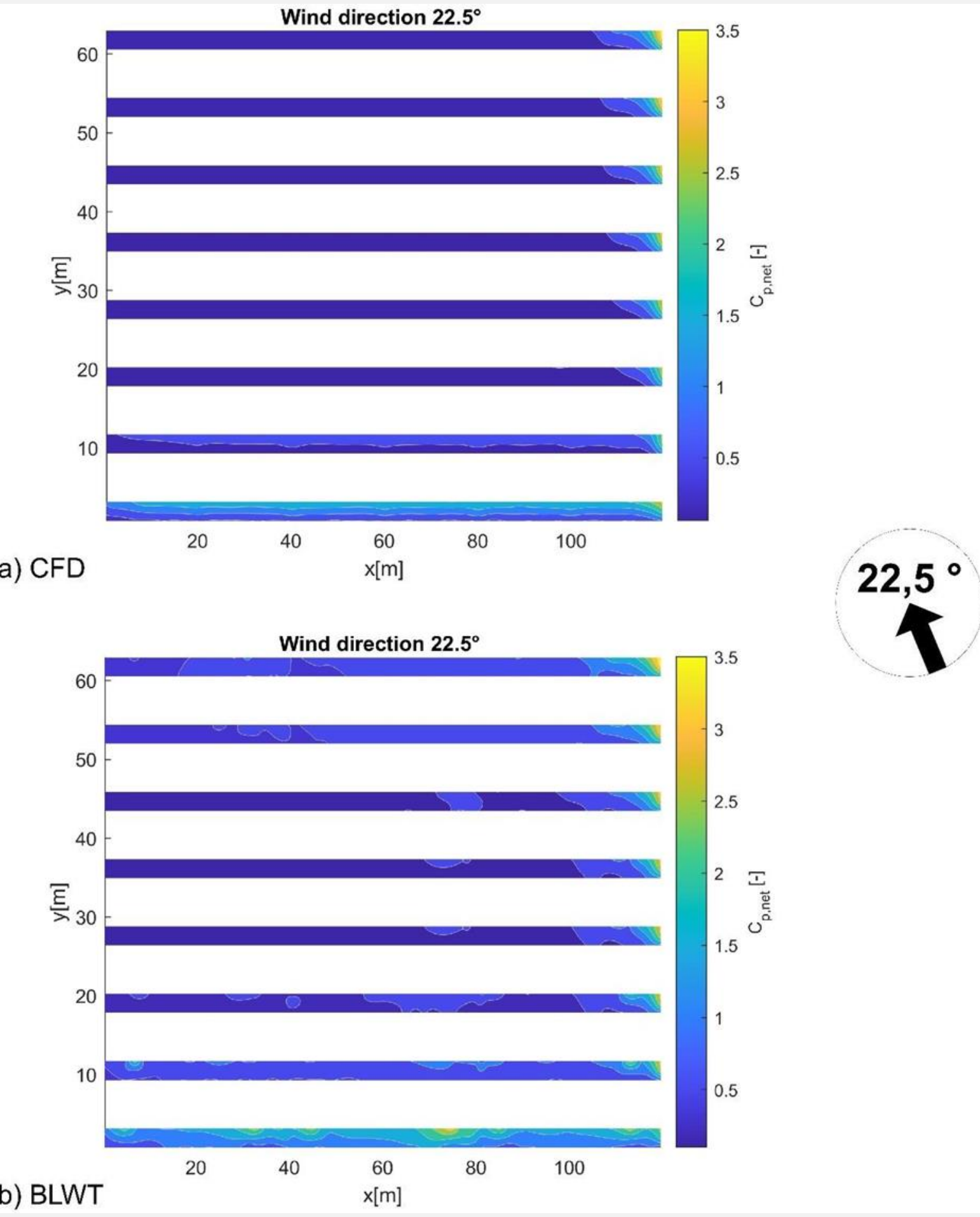

Figure 9. Net pressure coefficients distribution for wind direction $22.5^{\circ}$ : a) results from simulation, b) results from wind tunnel 

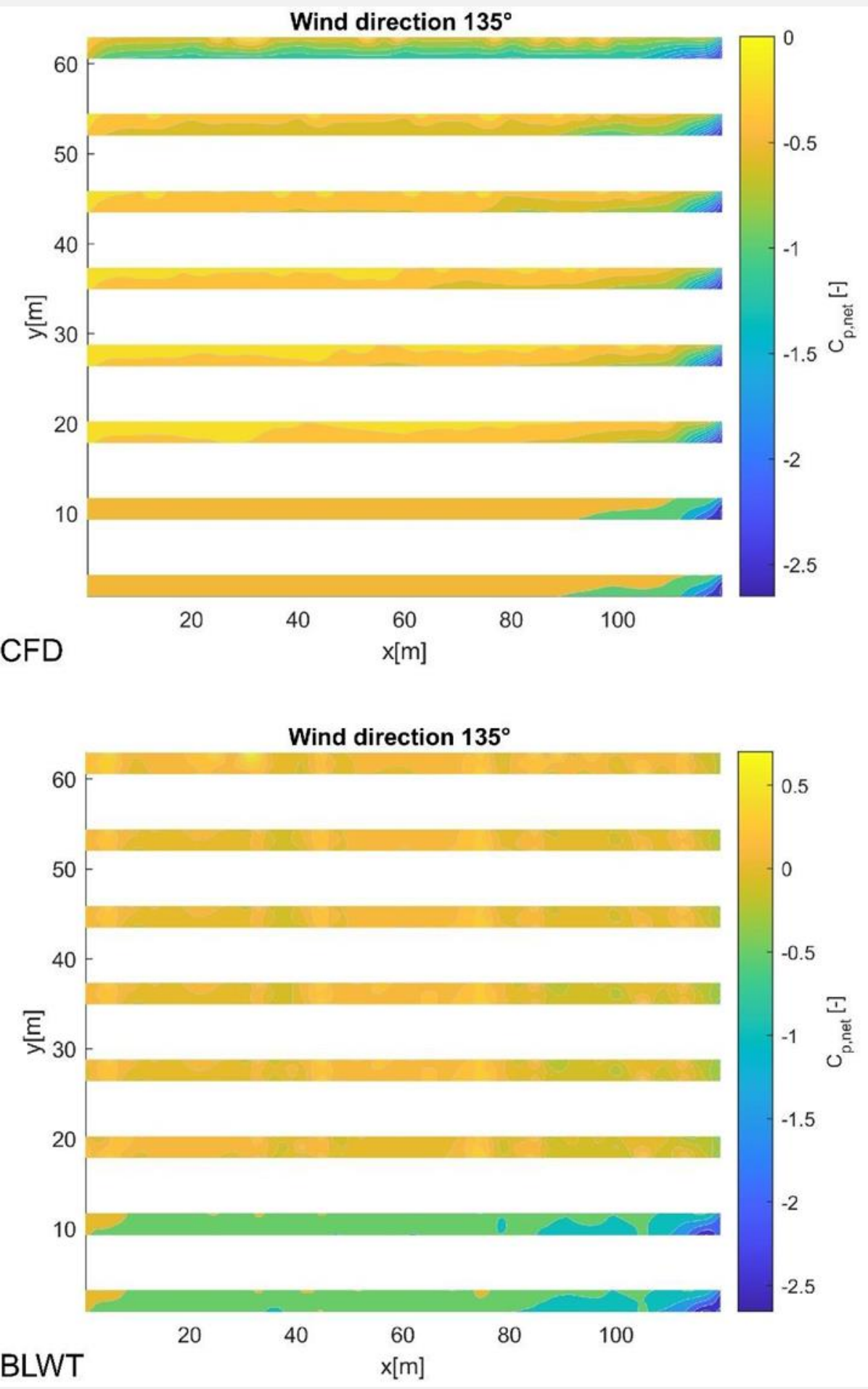

Figure 10. Net pressure coefficients distribution for wind direction $135^{\circ}$ : a) results from simulation, b) results from wind tunnel 

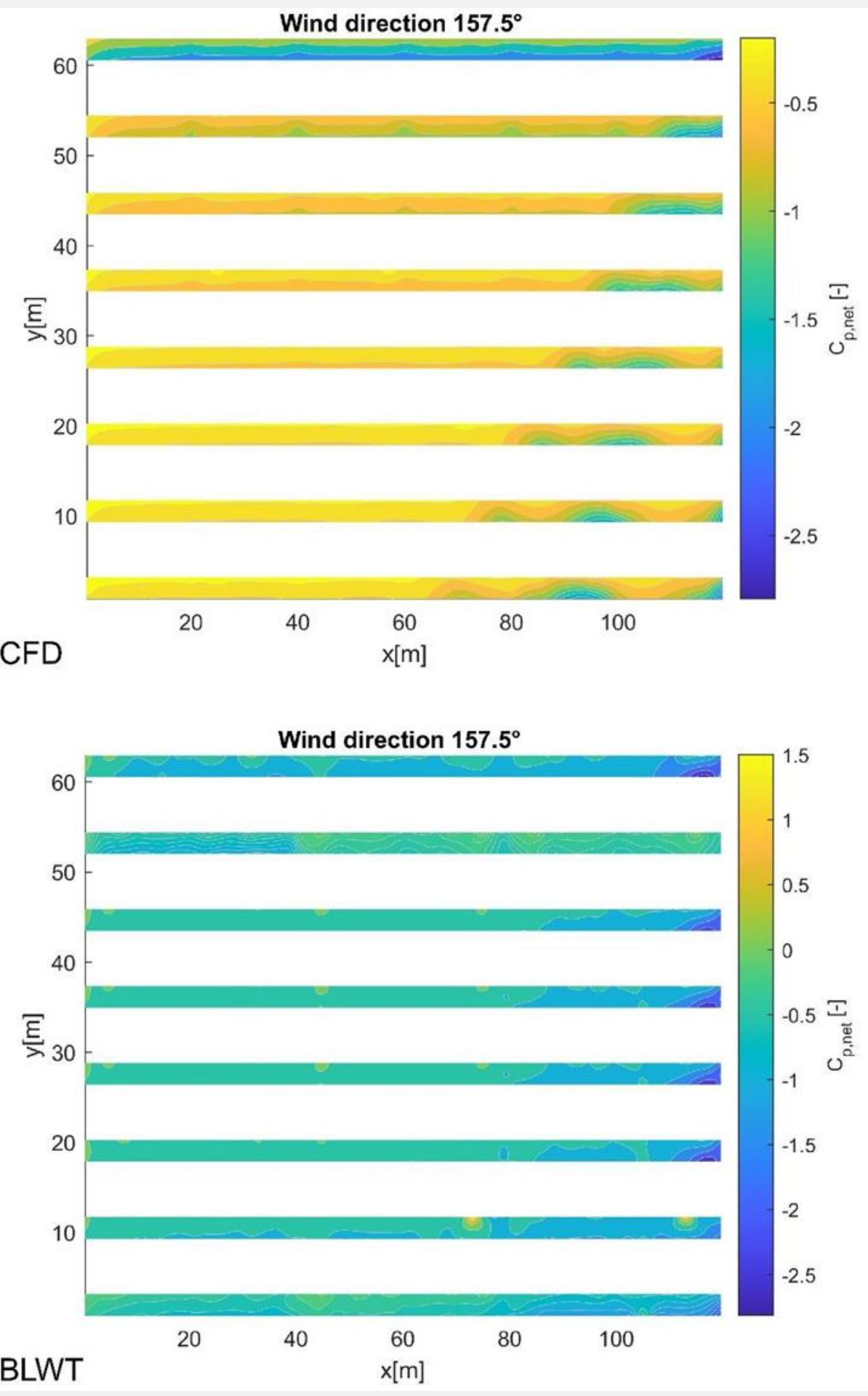

Figure 11. Net pressure coefficients distribution for wind direction $157.5^{\circ}$ : a) results from simulation, b) results from wind tunnel 

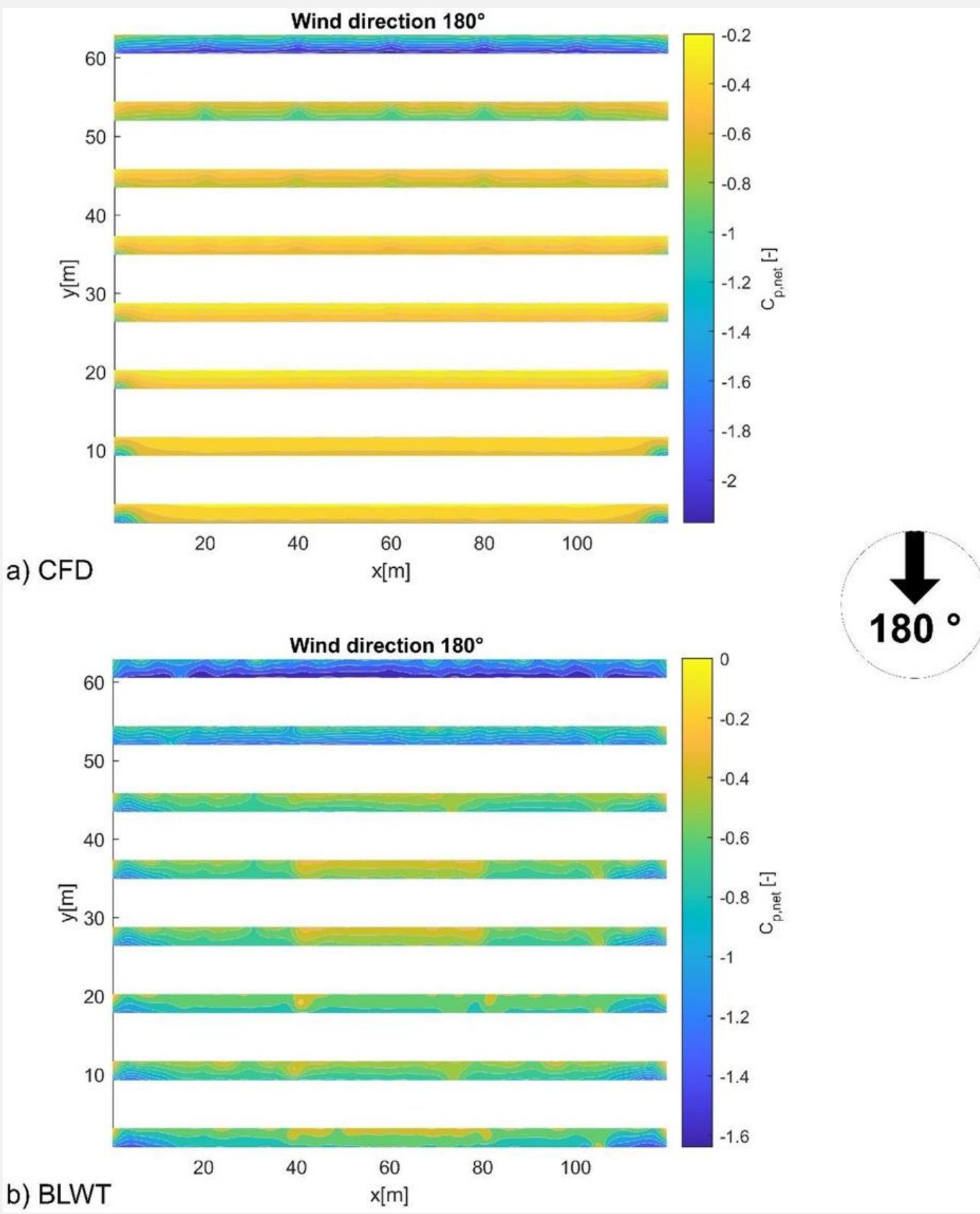

Figure 12. Net pressure coefficients distribution for wind direction $180^{\circ}:$ a) results from simulation, b) results from wind tunnel

\section{CONCLUSIONS}

The highest values of pressures occurred at wind flows of $22.5^{\circ}$ or $0^{\circ}$ and the highest suction was observed at wind directions $135^{\circ}, 157.5^{\circ}$ and $180^{\circ}$. The $0^{\circ}$ wind direction represents the south wind flow of the site. The results of experimental measurements are processed according to the methodology given in EN1991-1-4 [18], which determines the coefficients of net pressure in individual zones, considering areas loaded by pressure or suction and determines both values in individual zones.

Tab. 2 and Tab. 3 show a comparison of the extreme values of the coefficients of net pressure and suction obtained by CFD simulation, experimental measurements and STN EN 1991-1-4 for open shelters, where the designation of the row and position of panels $A, B, C$ in the assembly are shown in Figure 2. 
Table 2. Comparison of extreme values of wind pressure coefficients $c_{p, \text { net }}$ 1.

\begin{tabular}{|c|c|c|c|c|c|c|}
\hline \multirow{2}{*}{ row } & \multirow{2}{*}{$\begin{array}{c}\text { wind } \\
\text { direction }\end{array}$} & \multicolumn{2}{|c|}{ CFD } & \multicolumn{2}{|c|}{$\begin{array}{c}\text { Experimental } \\
\text { measurements in } \\
\text { BLWT }\end{array}$} & $\begin{array}{c}\text { EN 1991-1-4 } \\
\text { open canopies }\end{array}$ \\
\cline { 3 - 7 } & point & $\begin{array}{c}c_{p, n e t} \\
\text { pressure }\end{array}$ & point & $\begin{array}{c}c_{\text {p,net }} \\
\text { pressure }\end{array}$ & $\begin{array}{c}c_{p, n e t} \\
\text { pressure }\end{array}$ \\
\hline 1 & $22.5^{\circ}$ & B20 & 2.934 & B20 & 2.5 & 3.14 \\
\hline 2 & $22.5^{\circ}$ & B43 & 2.844 & B43 & 2.795 & 3.14 \\
\hline 3 & $22.5^{\circ}$ & B43 & 2.869 & B43 & 2.87 & 3.14 \\
\hline 4 & $22.5^{\circ}$ & B43 & 2.875 & B43 & 2.83 & 3.14 \\
\hline 7 & $22.5^{\circ}$ & B20 & 3.26 & B20 & 3.249 & 3.14 \\
\hline 8 & $0^{\circ}$ & B20 & 3.52 & B20 & 3.6 & 3.14 \\
\hline
\end{tabular}

Table 3. Comparison of extreme values of wind suction coefficients $c_{p, n e t}$

\begin{tabular}{|c|c|c|c|c|c|c|}
\hline \multirow{2}{*}{ row } & \multirow{2}{*}{$\begin{array}{l}\text { wind } \\
\text { direction }\end{array}$} & \multicolumn{2}{|c|}{ CFD } & \multicolumn{2}{|c|}{$\begin{array}{c}\text { Experimental } \\
\text { measurements in } \\
\text { BLWT }\end{array}$} & $\begin{array}{c}\text { EN 1991-1-4 } \\
\text { open canopies }\end{array}$ \\
\cline { 3 - 7 } & & point & $\begin{array}{c}c_{p, n e t} \\
\text { pressure }\end{array}$ & poin t & $\begin{array}{c}c_{p, n e t} \\
\text { pressure }\end{array}$ & $\begin{array}{c}c_{p, n e t} \\
\text { pressure }\end{array}$ \\
\hline 1 & $135^{\circ}$ & B43 & -2.523 & B39 & -2.659 & -3.44 \\
\hline 2 & $135^{\circ}$ & B43 & -2.482 & B39 & -2.544 & -3.44 \\
\hline 3 & $135^{\circ}$ & B40 & -2.234 & B39 & -2.497 & $-3,44$ \\
\hline 4 & $135^{\circ}$ & B40 & -2.25 & B39 & -2.496 & -3.44 \\
\hline 7 & $135^{\circ}$ & B40 & -2.26 & B39 & -2.415 & -3.44 \\
\hline 8 & $157.5^{\circ}$ & B40 & -2.77 & B39 & -2.764 & -3.44 \\
\hline
\end{tabular}

The aim of the CFD simulation and experimental research was to determine the coefficients of the resulting wind pressure on the solar panel system, since it is impossible to use the values from the standard. It can be seen that the inner panels are considerably less loaded than areas A for canopy roofs. The panels placed on the side of the assembly or on the edge of the aisle are loaded significantly more than parts B. Frontal panels are also less loaded by wind than areas $C$ in standard (see Tab. 1). The obtained values of wind effects on solar panels allow to optimize the design of supports of the whole set of panels and show the extremes of pressures and suction in the corners, which should be taken into account in the design. The inner parts of the panel assembly, where the wind load is significantly lower, can be designed more economically.

\section{ACKNOWLEDGEMENTS}

This work was supported by the Slovak Research and Development Agency under the contract no. APVV-160126 and by the Scientific Grant Agency of the Ministry of Education, Science, Research and Sport of the Slovak Republic and the Slovak Academy of Sciences in the project VEGA 1/0113/19. Presented results have been arranged due to the research supported by the Slovak Scientific Grant Agency, projects VEGA No. 1/0412/18 and No. 1/0453/20. 


\section{REFERENCES}

[1] Adrian, R., Axinte, E., Theohari, Ch. Steady wind pressures on solar collectors on flat-roofed buildings, Journal of Wind Engineering and Industrial Aerodynamics, Volume 23, 1986, Pages 249-258, ISSN 0167-6105, https://doi.org/10.1016/0167- 6105(86)90046-2.

[2] [7]ANSYS Inc., ANSYS Fluent Theory Guide, Release 18.1, 2017.

[3] [8]ANSYS Inc., ANSYS Fluent User's Guide, Release 19.1, 2018.

[4] Bitsuamlak, G.T., Dagnew, A.K., Erwin, J. Evaluation of wind loads on solar panel modules using CFD. In: Proceedings of the Fifth International Symposium on Computational Wind Engineering, Chapel Hill, North Carolina, USA, May 23-27, 2010.

[5] Blocken, B., STATHOPOULOS, T., CARMELIET, J., CFD simulation of the atmospheric boundary layer-wall function problems. Atmospheric Environment Volume 41(2), 2007, Pages 238-252. Elsevier.

[6] Bodhinayake, G. G., Ginger, J. D. \& Ingham, S. REPORT - Wind Loads on Ground Mounted Solar Panels, Issue April 2019.

[7] Browne, M. T. L., Gibbons, M. P. M., Gamble, S., \& Galsworthy, J. Wind loading on tilted roof-top solar arrays: The parapet effect. Journal of Wind Engineering and Industrial Aerodynamics, Volume 123, 2013, Pages 202-213.

https://doi.org/10.1016/j.jweia.2013.08.013

[8] Cermak, J. E. et al. Wind Tunnel Studies of Buildings and Structures : ASCE Manuals and Reports on Engineering Practice, 1999. Virginia: American Society of Civil Engineers. ISBN 0-78440319-8.

[9] Franke, J. et al. Best practice guideline for the CFD simulation of flows in the urban environment, COST Office Brussels, 2007.

[10] Franklin, H.A., 1983. Integrated Structure Designs for Photovoltaic Arrays, Report SAND81-7191. Bechtel Group, Inc., San Francisco, California, April 1983.

[11] Jubayer, C. M., \& Hangan, H. A numerical approach to the investigation of wind loading on an array of ground mounted solar photovoltaic (PV) panels. Journal of Wind Engineering and Industrial Aerodynamics, Volume 153, 2016, Pages 60-70. https://doi.org/10.1016/j.jweia.2016.03.009

[12] Kopp, G. A., Farquhar, S., \& Morrison, M. J. Aerodynamic mechanisms for wind loads on tilted, roof-mounted, solar arrays. Journal of Wind Engineering and Industrial Aerodynamics, Volume 111, 2012, Pages 40-52. https://doi.org/10.1016/j.jweia.2012.08.004
[13] Meroney, R.N., Neft, D.E. Wind effects on roofmounted solar photovoltaic arrays: CFD and windtunnel evaluation. In: Proceedings of the Fifth International Symposium on Computational Wind Engineering, 2010, Chapel Hill, North Carolina, USA.

[14] Miller, R.D., Zimmerman, D.K. Wind Loads on Flat Plate Photovoltaic Array Fields. Boeing Engineering and Construction Company, 1981, Seattle, Washington, USA.

[15] Naeiji, A., Raji, F., \& Zisis, I. Wind loads on residential scale rooftop photovoltaic panels. Journal of Wind Engineering and Industrial Aerodynamics, Volume 168(October 2016), Pages 228-246. https://doi.org/10.1016/j.jweia.2017.06.006

[16] Radu, A., Axinte, E. Wind forces on structures supporting solar collectors. Journal of Wind Engineering and Industrial Aerodynamics, Volume 32,1989, Pages 93-100.

[17] Shademan, M., Barron, R.M., Balachandar, R., Hangan, $\mathrm{H}$. Numerical simulation of wind loading on ground-mounted solar panels at different flow configurations. Can.J. Civ. Eng. Volume 41, 2014, Pages 728-738.

[18] STN EN 1991-1-4 (2007) Eurocode 1. Actions on structures. Part 1-4: General actions. Wind actions.

[19] STN EN 1991-1-4/NA (2008) Eurocode 1. Actions on structures. Part 1-4: General actions. Wind actions. National Annex.

[20] Strobel, K., \& Banks, D. Effects of vortex shedding in arrays of long inclined flat plates and ramifications for ground-mounted photovoltaic arrays. Journal of Wind Engineering and Industrial Aerodynamics, Volume 133, 2014, Pages 146-149. https://doi.org/10.1016/j.jweia.2014.06.013

[21] Tominaga, Y. AlJ guidelines for practical applications of CFD to pedestrian wind environment around buildings, J Wind Eng Ind Aerod, Volueme 96, (10-11) 2008, Pages 1749-1761.

[22] Warsido, W. P., Bitsuamlak, G. T., Barata, J., \& Gan Chowdhury, A. Influence of spacing parameters on the wind loading of solar array. Journal of Fluids and Structures, Volume 48, 2014, Pages 295-315. https://doi.org/10.1016/j.jfluidstructs.2014.03.005 
NUMERICAL AND EXPERIMENTAL DETERMINATION OF WIND LOAD ON PHOTOVOLTAIC PANEL ASSEMBLIES

Olga HUBOVÁ

Michal FRANEK

Marek MACÁK

The article presents the aerodynamic study of solar panel assemblies and determination of wind load. In the first part, the task is solved by computer simulation of the wind flow around the proposed rectangular assembly in the scale of $1: 1$ using the FLUENT ANSYS program; realization of experimental measurements in the wind tunnel with a boundary layer (BLWT) in Bratislava is presented subsequently. The aim of the solution was to determine the maximum pressure and suction wind load on top and bottom surfaces of panels. The resulting net pressure coefficient represents the maximum local pressure in each panel row as maximum values from all wind directions. The experimentally obtained net pressure coefficient values were compared with computer simulation and the procedures mentioned in standard STN EN 1991-1-4. It can be seen that the inner panels are loaded considerably less than the standard defines. The panels placed on the side of the assembly or on the edge of the aisle are loaded significantly more than the standard defines. Frontal panels are also less wind stressed than in the standard defines.

Key words: Photovoltaic Panel, Wind Tunnel, Computational Fluid Dynamics, Net Pressure Coefficient, Wind Load

\section{APSTRAKT}

NUMERIČKO I EKSPERIMENTALNO ODREĐIVANJE OPTEREĆENJA KOJE VETAR VRŠI NA SKLOPOVE FOTONAPONSKE PLOČE

Ol'ga HUBOVÁ

Michal FRANEK

Marek MACÁK

Rad predstavlja prikaz aerodinamičke studije na sklopovima solarnih ploča i određivanje opterećenja koje vetar vrši na njih. $U$ prvom delu istraživanje je obavljeno računarskom simulacijom protoka vetra oko predloženog pravougaonog sklopa u odnosu 1:1 primenom programa FLUENT ANSYS. Nakon toga predstavljena su eksperimentalna merenja iz aerodinamičkog tunela sa graničnim slojem (BLWT) u Bratislavi. Cilj je bio da se odredi maksimalni pritisak i usisno opterećenje vetra na svakom nizu panela iz svakog pravca duvanja vetra. Eksperimentalno dobijene ukupne vrednosti za koeficijent pritiska upoređene su sa vrednostima dobijenim iz računarske simulacije i procedurama iz standarda STN EN 1991-1-4. Može se videti da su unutrašnji paneli znatno manje opterećeni od onoga kako je u standardu definisano. Paneli smešteni na bočnim stranama ili po ivici znatno su više opterećeni od onoga kako je u standardu definisano. Frontalni paneli su takođe manje opterećeni delovanjem vetra nego što standard definiše.

Ključne reči: solarni panel, aerodinamički tunel, računarska dinamika fluida, ukupni koeficijent pritiska, opterećenje vetra 